\title{
Glucocorticoids impair oocyte competence and trigger apoptosis of ovarian cells via activating the TNF- $\alpha$ system
}

\author{
Hong-Jie Yuan*, Zhi-Bin Li*, Xin-Yue Zhao, Guang-Yi Sun, Guo-Liang Wang, Ying-Qi Zhao, \\ Min Zhang and Jing-He Tan \\ Shandong Provincial Key Laboratory of Animal Biotechnology and Disease Control and Prevention, College of \\ Animal Science and Veterinary Medicine, Shandong Agricultural University, Tai'an City, People's Republic of China \\ Correspondence should be addressed to J-H Tan; Email: tanjh@sdau.edu.cn
}

*(H-J Yuan and Z-B Li contributed equally to this work)

\begin{abstract}
Mechanisms by which female stress and particularly glucocorticoids impair oocyte competence are largely unclear. Although one study demonstrated that glucocorticoids triggered apoptosis in ovarian cells and oocytes by activating the FasL/Fas system, other studies suggested that they might induce apoptosis through activating other signaling pathways as well. In this study, both in vivo and in vitro experiments were conducted to test the hypothesis that glucocorticoids might trigger apoptosis in oocytes and ovarian cells through activating the TNF- $\alpha$ system. The results showed that cortisol injection of female mice (1.) impaired oocyte developmental potential and mitochondrial membrane potential with increased oxidative stress; (2.) induced apoptosis in mural granulosa cells (MGCs) with increased oxidative stress in the ovary; and (3.) activated the TNF- $\alpha$ system in both ovaries and oocytes. Culture with corticosterone induced apoptosis and activated the TNF- $\alpha$ system in MGCs. Knockdown or knockout of TNF- $\alpha$ significantly ameliorated the pro-apoptotic effects of glucocorticoids on oocytes and MGCs. However, culture with corticosterone downregulated TNF- $\alpha$ expression significantly in oviductal epithelial cells. Together, the results demonstrated that glucocorticoids impaired oocyte competence and triggered apoptosis in ovarian cells through activating the TNF- $\alpha$ system and that the effect of glucocorticoids on TNF- $\alpha$ expression might vary between cell types.

Reproduction (2020) $\mathbf{1 6 0} 129-140$
\end{abstract}

\section{Introduction}

Stresses of various types can affect female reproduction in both humans and animals. For example, thin women with a poor psychological profile are at increased risk of giving birth to preterm infants when depressed during pregnancy (Neggers et al. 2006), and the state anxiety of women had a significant influence on their outcome of IVF treatment (Csemiczky et al. 2000, Kee et al. 2000, Klonoff-Cohen et al. 2001, Schröder et al. 2004). In dairy cows, the heat stress-induced alterations in small antral follicles can lead to compromised maturation and developmental capacity of ovulating oocytes (Roth 2017). Furthermore, exposure of pregnant mice and rats to restraint stress, an effective procedure to mimic the human psychological stress (Paré \& Glavin 1986, Glavin et al. 1994), impaired function of corpora lutea and decreased pregnancy rates and litter size (Wiebold et al. 1986, Sugino et al. 1994). However, evidences on the direct effect of stress on the oocyte are limited. Although recent studies indicated that heat stress of dairy cows (Roth 2017) and restraint stress of female mice (Zhang et al. 2011) significantly impaired oocyte developmental potential, the underlying mechanisms are largely unknown.

It is known that stresses activate the hypothalamuspituitary-adrenal (HPA) axis and increases secretion of glucocorticoids from the adrenal cortex. For example, heat stress in workers can lead to an increase in blood levels of stress hormones including cortisol with cognitive performance impairment (Mazlomi et al. 2017). Heat stress in dairy cows significantly increased blood cortisol and reduced milk yield irrespective of the genetic makeup (Ihsanullah et al. 2017). Furthermore, mice and rats exposed to various stresses showed significant elevation in serum corticosterone (MacNiven et al. 1992, Kim et al. 2008, Gong et al. 2015) and cortisol (Yin et al. 2007, Zhang et al. 2011, Gong et al. 2015). However, although the previously mentioned data suggested that stressors impaired oocyte competence through activating the HPA axis and increasing secretion of glucocorticoids, treatment of mouse oocytes directly with physiological or stress-induced concentrations of cortisol (Andersen 2003, Zhang et al. 2011) or corticosterone (González et al. 2010) during in vitro maturation did not affect nuclear maturation and embryo development. Thus, 
the mechanisms by which glucocorticoids damage the oocyte are worth exploring.

Glucocorticoids triggered Leydig cell death with activation of the Fas system and increased ROS generation (Gao et al. 2003). Treatment of osteoblasts with dexamethasone and tumor necrosis factor (TNF)- $\alpha$ promoted their apoptosis (Almeida et al. 2011). Furthermore, our previous studies demonstrated that the restraint-induced $\mathrm{CRH}$ elevation impaired developmental potential of mouse oocytes by triggering apoptosis of ovarian cells and oocytes within the ovary through activating the Fas system (Liang et al. 2013, Li et al. 2018). We thus hypothesized that glucocorticoids might also impair oocyte competence indirectly by inducing apoptosis of ovarian cells and oocytes during their development within the ovary. We tested this hypothesis by injecting female mice with cortisol, and the results confirmed that glucocorticoids impaired oocyte competence by triggering apoptosis in ovarian cells including the oocyte through activating the FasL/Fas system (Yuan et al. 2016). However, recent studies have shown that restraint stress caused apoptosis in oviductal (Zheng et al. 2016) and spermatogenic cells (Xiao et al. 2019) as well in the gld mice with a FasL mutation, although to a less severe degree compared with that in the WT mice. This suggests that glucocorticoids may induce apoptosis in ovarian cells and oocytes by activating other signaling pathways in addition to the Fas system.

Both the TNF receptor (TNFR) and the Fas receptor are members of the TNFR superfamily, which can induce cell apoptosis through binding their respective ligands (Kavurma et al. 2008). Previous studies have shown that the TNF- $\alpha$ system is active in mammalian ovaries. For instance, human oocytes and cumulus cells express TNF- $\alpha$ and its receptor TNFR2 both at the mRNA and protein levels (Naz et al. 1997). Rat oocytes, granulosa cells, and interstitial cells express TNFR and rat oocytes can produce TNF- $\alpha$ (Marcinkiewicz et al. 2002). Expression of TNF- $\alpha$ system members was observed in bovine ovarian follicles (Silva et al. 2017). In vitro treatment with TNF- $\alpha$ impaired maturation of bovine oocytes leading to compromised development of embryos (Soto et al. 2003). Mouse oocytes express both TNFR1 and TNFR2 and they are therefore sensitive to TNF-induced cell death (Greenfeld et al. 2007). Furthermore, treatment of bovine oocytes with 9-cis retinoic acid improved developmental potential with downregulated TNF- $\alpha$ expression (Deb et al. 2011).

We therefore proposed that glucocorticoids might impair oocyte competence by triggering apoptosis of oocytes and ovarian cells through activating the TNF- $\alpha$ system during oocyte growth and maturation within the ovary. Both in vivo and in vitro experiments were conducted to test this hypothesis. In the in vivo experiments, female mice were injected with cortisol before examination for oocyte developmental potential and the redox state, apoptosis, and activation of the TNF- $\alpha$ system in oocytes and ovarian cells. In the in vitro experiments, mural granulosa cells (MGCs) were cultured with corticosterone before examination for apoptosis and activation of the TNF- $\alpha$ system. Finally, TNF- $\alpha$ was knocked down in MGCs in vitro by RNAi and knocked out in vivo by using the TNF- $\alpha-/-$ mice to confirm the role of the TNF- $\alpha$ system in mediating the pro-apoptotic effects of glucocorticoids on oocytes and MGCs.

\section{Materials and methods}

Procedures for animal care and handling were carried out exactly in accordance with the guidelines approved by the Shandong Agriculture University Animal Care and Use Committee, P. R. China (Permit number: SDAUA-2019-004). If not mentioned otherwise, all the chemicals and reagents used in this study were purchased from Sigma Chemical Co.

\section{Animals and treatment}

Most of the experiments in this study used the Kunming mice, which were bred in this laboratory. The TNF- $\alpha^{-/}$mice with a C57BL/6J genomic background were obtained from Model Animal Research Center of Nanjing University, Nanjing, China, and the WT C57BL/6J mice were purchased from Shandong University Center for Laboratory Animals. The mice were raised in rooms under a $14 \mathrm{~h}$ light:10 $\mathrm{h}$ darkness photoperiod, with lights turned off at $2000 \mathrm{~h}$. At age of 8-12 weeks after birth, female mice were injected intra-peritoneally with $10 \mathrm{IU}$ of eCG, and at $24 \mathrm{~h}$ after eCG injection, while cortisol-injected mice were injected with $50 \mathrm{mg} / \mathrm{kg}$ cortisol, the ethanol-injected control mice were injected with $50 \%$ ethanol vehicle. This dose of cortisol injection was chosen based on our previous study, which tested 0,10 , and $50 \mathrm{mg} / \mathrm{kg}$ and found that cortisol levels in both serum and ovaries were similar between mice injected with $50 \mathrm{mg} / \mathrm{kg}$ cortisol and the restraint stressed mice but were significantly higher than that in mice injected with $10 \mathrm{mg} / \mathrm{kg}$ bodyweight (Yuan et al. 2016). Cortisol was dissolved in $50 \%$ alcohol in saline and was administrated intra-peritoneally. Procedures for preparation of cortisol stock solution and injection were conducted exactly as we reported previously (Yuan et al. 2016).

\section{Collection of ovaries, oocytes, and mural granulosa cells (MGCs)}

At $24 \mathrm{~h}$ after cortisol injection or $48 \mathrm{~h}$ following eCG injection, mice were killed to recover ovaries. The large follicles on the ovary were ruptured in M2 medium to release oocytes. Only oocytes with more than three layers of unexpanded cumulus cells, containing oocytes larger than $70 \mu \mathrm{m}$ in diameter, and with a homogenous cytoplasm were used for experiments. The MGCs sheets released into M2 medium at puncture of follicles were collected for further use. 


\section{In vitro maturation of oocytes}

Oocytes recovered were washed three times in M2 medium and once in the maturation medium. Then, 20-30 oocytes were cultured in a $100 \mu \mathrm{L}$ drop of maturation medium at $37.5^{\circ} \mathrm{C}$ in a humidified atmosphere of $5 \% \mathrm{CO}_{2}$ in air. The maturation medium used for routine in vitro maturation was TCM-199 (Gibco) containing 10\% (v/v) fetal calf serum (Gibco), $1 \mu \mathrm{g} /$ $\mathrm{mL}$ of $17 \beta$-estradiol, $24.2 \mathrm{mg} / \mathrm{L}$ of sodium pyruvate, $0.05 \mathrm{IU} /$ $\mathrm{mL}$ of $\mathrm{FSH}, 0.05 \mathrm{IU} / \mathrm{mL}$ of $\mathrm{LH}$, and $10 \mathrm{ng} / \mathrm{mL}$ of EGF. However, in the maturation medium used to prepare conditioned medium for TNF- $\alpha$ assay, serum, growth factor, and hormone $(\mathrm{SGH})$ were omitted and $24.2 \mathrm{mg} / \mathrm{L}$ of sodium pyruvate and $0.3 \mathrm{mg} / \mathrm{mL}$ of polyvinyl alcohol were supplemented, because our previous studies had shown that the adverse effect of stress or glucocorticoids on oocytes could be observed immediately after in vitro maturation only when oocytes were matured in a poor medium without SGH (Liang et al. 2013, Yuan et al. 2016).

\section{In vitro fertilization}

Male mice were killed by cervical dislocation at 10-12 weeks after birth and cauda epididymidis and vas deferens were removed and placed in 35-mm sterile plastic dishes containing simple PBS. Caudae epididymides and vasa deferentia were cut several times with the edge of an injection needle and squeezed to release sperm masses. Then, the sperm masses were transferred to a drop of $1 \mathrm{~mL}$ T6 medium with $10 \mathrm{mg} / \mathrm{mL}$ BSA and incubated at $37^{\circ} \mathrm{C}$ in a $\mathrm{CO}_{2}$ incubator to allow spermatozoa to swim out. After the sperm concentration of the sperm suspension was adjusted with the same medium to $2-4 \times 10^{7} \mathrm{sperm} / \mathrm{mL}$, the spermatozoa were incubated for $2 \mathrm{~h}$ for capacitation. After being washed in the fertilization medium (T6 with $20 \mathrm{mg} / \mathrm{mL}$ BSA), oocytes recovered at $14 \mathrm{~h}$ of maturation culture were placed in the fertilization drops (about 20 oocytes/40 $\mu \mathrm{L}$ drop). Capacitated spermatozoa were added to the fertilization drops to give a final sperm concentration of about $1 \times 10^{6} / \mathrm{mL}$. After $6 \mathrm{~h}$ of incubation, zygotes with two pronuclei and the second polar body were selected for embryo culture.

\section{Oocyte activation}

After maturation culture for $24 \mathrm{~h}$, oocytes were freed of cumulus cells by repeatedly pipetting in M2 containing $0.1 \%$ hyaluronidase. After being washed twice in M2 and once in the activating medium, the oocytes were incubated in the activating medium for $6 \mathrm{~h}$ at $37.5^{\circ} \mathrm{C}$ in a humidified atmosphere with $5 \% \mathrm{CO}_{2}$ in air. The activating medium was $\mathrm{Ca}^{2+}$-free CZB medium supplemented with $10 \mathrm{mM} \mathrm{SrCl}_{2}$ and $5 \mu \mathrm{g} / \mathrm{mL}$ cytochalasin B. At the end of the activation treatment, oocytes were examined for activation under a microscope. Oocytes were considered activated when each contained one or two well-developed pronuclei.

\section{Embryo culture}

Zygotes obtained from in vitro fertilization or activated oocytes generated by $\mathrm{Sr}^{2+}$ activation were cultured in regular CZB medium (about 30 zygotes/oocytes per $100 \mu \mathrm{L}$ drop) at $37.5^{\circ} \mathrm{C}$ in humidified atmosphere containing $5 \% \mathrm{CO}_{2}$ in air. Glucose (5.5 mM) was added to CZB when embryos developed beyond 3- or 4-cell stages. At the end of the embryo culture, embryo development was examined and some of the blastocysts were stained with Hoechst 33342 for cell counting.

\section{Assays for intra-oocyte reactive oxygen species (ROS)}

Intra-oocyte ROS was measured by detecting $\mathrm{H}_{2} \mathrm{O}_{2}$ concentrations using 2',7'-dichlorodihydro-fluorescein diacetate (DCHFDA). To prepare a stock solution (1 mM), DCHFDA was dissolved in DMSO and the stock solution was stored in the dark at $-20^{\circ} \mathrm{C}$. Immediately before use, the stock solution was diluted to $10 \mu \mathrm{M}$ in $\mathrm{M} 2$ medium and oocytes that had been freed of cumulus cells were stained in the resultant solution at $37^{\circ} \mathrm{C}$ for $10 \mathrm{~min}$. Following staining, the oocytes were washed several times in $M 2$, placed on a slide, and examined under a confocal microscope (Leica, TCS SP2) with fluorescence obtained by excitation at $488 \mathrm{~nm}$. All the photographs were taken using the same microscopic parameters. A Leica software was used to analyze the fluorescence intensity of each oocyte.

\section{Measurement of oocyte mitochondrial membrane potential (MMP)}

Oocyte MMP was measured using a MMP detection kit (Beyotime Biotechnology Research Institute, China). Cumulusfree oocytes were washed three times in $M 2$, placed in a drop containing $1 \mathrm{~mL} \mathrm{M} 2$ and $1 \mathrm{~mL} \mathrm{JC}-1$ dye working solution, and incubated at $37^{\circ} \mathrm{C}$ for $25 \mathrm{~min}$. After being washed three times with a JC-1 staining buffer, the oocytes were observed under a Leica confocal microscope. The same oocytes were observed through TRITC channel (red fluorescence) and FITC channel (green fluorescence). The aggregate JC-1 (red fluorescence) was detected at an emission wave length of $590 \mathrm{~nm}$, while the monomeric JC-1 (green fluorescence) was monitored at 529 $\mathrm{nm}$. The ratio of aggregate/monomeric JC-1 was calculated to quantify changes in MMP, and a decreased red/green JC-1 ratio represented depolarization of the mitochondria.

\section{Terminal deoxynucleotidyl transferase dUTP nick end labeling (TUNEL)}

We dispersed MGCs by pipetting in M2 medium. We concentrated the dispersed MGCs by centrifugation at 200 $\mathbf{g}$ for $5 \mathrm{~min}$ after washing them three times in $\mathrm{M} 2$. We then resuspended the pellets with $20 \mu \mathrm{L} \mathrm{M} 2$ and smeared $5 \mu \mathrm{L}$ of the suspension on a slide. After the slides were dried thoroughly in air, we stained them using an in situ cell death detection kit (KGA 703, KeyGEN) as follows: (1.) fixation for $5 \mathrm{~min}$ in $4 \%$ paraformaldehyde at room temperature; (2.) treatment for 5 min with $1 \%$ cold Triton X-100; (3.) incubation for 5 min in $50 \mu \mathrm{L}$ terminal deoxynucleotidyl transferase $(\mathrm{TdT})$ reaction solution (45 $\mu \mathrm{L}$ equilibration buffer, $1 \mu \mathrm{L}$ biotin-11-dUTP, and $4 \mu \mathrm{L} \mathrm{TdT}$ enzyme) at $37^{\circ} \mathrm{C}$ in darkness; (4.) incubation for $30 \mathrm{~min}$ in $50 \mu \mathrm{L}$ streptavidin- fluorescein labeling solution (45 $\mu \mathrm{L}$ labeling buffer and $5 \mu \mathrm{L}$ streptavidin-fluorescein) at 
$37^{\circ} \mathrm{C}$ in darkness; and (5.) incubation for $10 \mathrm{~min}$ in $10 \mu \mathrm{g} /$ $\mathrm{mL}$ Hoechst 33342 to stain the nucleus. We then covered the stained smears with coverslips and observed them under a Leica fluorescence microscope. In each smear, we observed three fields to calculate percentages of TUNEL- positive cells from the number of Hoechst-stained nuclei. We determined numbers of the TUNEL-positive cells by using the Image J software.

\section{Preparation for blood serum and ovarian homogenates}

Trunk blood was collected from mice, put into ice-cooled centrifugal tubes, and centrifuged $\left(1700 \mathrm{~g}, 10 \mathrm{~min}, 4^{\circ} \mathrm{C}\right)$ to separate serum. The serum obtained was stored at $-80^{\circ} \mathrm{C}$ until use. For homogenization, ovaries were snap-frozen in liquid nitrogen immediately after removal from the mice. The frozen ovaries were weighed and transferred to an electrical homogenizer (ULTRA TURRAX IKA T18 basic) with proper amount of homogenization solution. Homogenization was performed while cooling on ice. The homogenates obtained were centrifuged $\left(15,000 \mathrm{~g}, 10 \mathrm{~min}, 4^{\circ} \mathrm{C}\right)$, and the supernatant was collected for immediate use or stored at $-80^{\circ} \mathrm{C}$ until use.

\section{Culture and treatment of MGCs and oviductal epithelial cells (OECs)}

Sheets of MGC released into M2 medium when follicles were punctured were recovered. Oviducts recovered at the same time as ovaries were collected, cut into small pieces, and squeezed to extrude the mucosal tissue. The cell pellets obtained were centrifuged at $200 \mathrm{~g}$ for $5 \mathrm{~min}$. After centrifugation, the pellets were digested for $10 \mathrm{~min}$ with $0.25 \%$ trypsin at $37.5^{\circ} \mathrm{C}$ and were washed twice by centrifugation (200 $\mathrm{g}$ for $5 \mathrm{~min}$ ). The pellets were then resuspended in DMEM/F12 (Gibco) supplemented with $10 \%(\mathrm{v} / \mathrm{v})$ fetal calf serum (Gibco) and $0.5 \%(\mathrm{v} / \mathrm{v})$ penicillin-streptomycin solution (Gibco). After the cell concentration was adjusted to $1 \times 10^{5}$ cells $/ \mathrm{mL}, 2 \mathrm{~mL}$ of the final suspension was added to each well of a 6 -well culture plate and cultured at $37.5^{\circ} \mathrm{C}$ in a humidified atmosphere of $5 \% \mathrm{CO}_{2}$ in air. To study the effects of corticosterone supplementation on cultured MGCs, when cells grew to $70-80 \%$ of confluence, the medium was renewed and cells were cultured for $24 \mathrm{~h}$ in serum- and antibiotics-free DMEM/ F12 medium with or without $10^{-5} \mathrm{M}(2 \mu \mathrm{L})$ of corticosterone and/or of RU486. To prepare stock solutions, corticosterone $\left(10^{-2} \mathrm{M}\right)$ was dissolved in dimethyl sulfoxide (DMSO) and RU486 $\left(10^{-2} \mathrm{M}\right)$ was dissolved in absolute alcohol. The stock solutions were stored at $-20^{\circ} \mathrm{C}$ until use. Control cells were cultured in serum- and antibiotics-free DMEM/F12 medium containing $2 \mu \mathrm{L}$ of DMSO and/or ethanol.

\section{Enzyme-linked immunosorbent assay (ELISA)}

Total antioxidant status (TAS) and total oxidant status (TOS) in serum and ovarian homogenates were measured using Mouse TAS ELISA Kit (SU-B20662) and Mouse TOS ELISA Kit (SU-B20663) purchased from Quanzhou Kenuodi Biological Technology Co., Ltd. Levels of TNF- $\alpha$ in serum, ovarian homogenates, conditioned medium, MGCs, and OECs were measured by ELISA using a mouse tumor necrosis factor $\alpha$ (TNF $\alpha$ ) Elisa kit (BLUE GENE, Shanghai, China). The intraassay $\mathrm{CV}(\%)$ and inter-assay $\mathrm{CV}(\%)$ for all the kits were less than $10 \%$. The detection limit for TOS/TAS assays was $0.1 \mathrm{U} /$ $\mathrm{mL}$ and that for TNF- $\alpha$ assay was $1 \mathrm{pg} / \mathrm{mL}$. Cultured MGCs were dispersed by repeatedly pipetting in PBS containing $0.25 \%$ trypsin and the cells were then lysed by the freezethaw method to release proteins. To conduct the ELISA assay, (1.) $100 \mu \mathrm{L}$ of standards or samples were added in duplicate to wells of a micro-titer plate that had been coated with mouse monoclonal antibodies; (2.) $50 \mu \mathrm{L}$ of conjugate was added to each well and incubated for $60 \mathrm{~min}$ at $37^{\circ} \mathrm{C}$; (3.) the micro-titer plate was washed using the wash solution and dried using paper towels; and (4.) $50 \mu \mathrm{L}$ of substrate A and 50 $\mu \mathrm{L}$ of substrate $\mathrm{B}$ were added to each well and incubated for $15 \mathrm{~min}$ at $25^{\circ} \mathrm{C}$. The optical density was measured at $450 \mathrm{~nm}$ using a plate reader (BioTek-ELx808, BioTek Instruments, Inc.) within $15 \mathrm{~min}$ after the reaction was terminated by $50 \mu \mathrm{L}$ of stop solution. The concentrations of TAS, TOS, and TNF- $\alpha$ were calculated against their respective standard curves.

\section{Western blot}

The MGCs were placed in a microfuge tube with $50 \mu \mathrm{L}$ RIPA buffer $(150 \mathrm{mM} \mathrm{NaCl}, 1.0 \%$ Triton X-100, 0.5\% sodium deoxycholate, $0.1 \%$ SDS, $1 \mathrm{mM}$ phenylmethyl sulfonyl fluoride, and $50 \mathrm{mM}$ Tris, $\mathrm{pH} 8$ ) and were lysed for $30 \mathrm{~min}$. After a 5-min centrifugation at $300 \mathrm{~g}$, supernatant was recovered and frozen-stored at $-80^{\circ} \mathrm{C}$ until use. To extract protein, $20 \mu \mathrm{L}$ of the supernatant and $6.67 \mu \mathrm{L} 4 \times$ SDS-PAGE loading buffer were put in each microfuge tube and the tubes were heated to $100^{\circ} \mathrm{C}$ for $5 \mathrm{~min}$. SDS-PAGE was run on a $12 \%$ polyacrylamide gel to separate total proteins, and the proteins obtained were transferred electrophoretically onto polyvinylidene fluoride membranes. The membranes were then (1.) washed in TBST (150 mM NaCl, $2 \mathrm{mM} \mathrm{KCl}, 25 \mathrm{mM}$ Tris, and 0.05\% Tween 20; $\mathrm{pH} 7.4$ ); (2.) blocked with TBST containing 3\% BSA at $37^{\circ} \mathrm{C}$ for $2 \mathrm{~h}$; (3.) incubated at $4^{\circ} \mathrm{C}$ overnight with primary antibodies; (4.) washed in TBST; and (5.) incubated for $1.5 \mathrm{~h}$ at $37^{\circ} \mathrm{C}$ with secondary antibodies. The primary antibodies used included rabbit anti TNFR polyclonal antibodies (1:1000, ab19139, Abcam Co., Ltd) and mouse anti-GAPDH antibodies (1:1000, CW0100M, CWBio Co., Ltd), and the secondary antibodies included goat anti-rabbit IgG (1:2000, CW0111, CWBio Co., Ltd, Beijing, China) and goat anti-mouse IgG (1:2000, CW0110, CWBio Co., Ltd). Signals were detected using a 5-bromo-4-chloro-3-indolyl phosphate/tetranitroblue tetrazolium chloride alkaline phosphatase color development kit (Beyotime Institute of Biotechnology). The sum density of each protein band image was analyzed using an Image-Pro Plus software (Media Cybernetics, Inc., Silver Spring, MD, USA). The density value of each sample was normalized to that of internal control, GAPDH, to get its relative quantity value.

\section{Quantification of TNFR1 in oocytes by immunofluorescence microscopy}

Cumulus-free oocytes were (1.) fixed for 30 min with $3.7 \%$ paraformaldehyde contained in PBS; (2.) treated with $0.5 \%$ 
protease for $10 \mathrm{~s}$ to remove zona pellucida; (3.) permeabilized for 10 min with $0.1 \%$ Triton $\mathrm{X}-100$ in PBS at $37.5^{\circ} \mathrm{C}$; and (4.) blocked for 30 min with $3 \%$ BSA in PBS at $37.5^{\circ} \mathrm{C}$; (5.) incubated at $4^{\circ} \mathrm{C}$ overnight with rabbit polyclonal antiTNF-R1 (IgG, 1:100, Abcam) in 3\% BSA in M2 medium; (6.) incubated for $1 \mathrm{~h}$ with Cy3-conjugated goat-anti-rabbit IgG (1:800, Jackson ImmunoResearch) in 3\% BSA in M2; and (7.) incubated for $10 \mathrm{~min}$ with $10 \mu \mathrm{g} / \mathrm{mL}$ Hoechst 33342 in M2 to stain chromatin. As negative controls, samples with the primary antibody omitted were also processed. The stained oocytes were mounted on glass slides and observed under a Leica laser scanning confocal microscope (TCS SP2). Blue diode (405 $\mathrm{nm}$ ) and helium/neon (543 nm) lasers were used to excite Hoechst and Cy3, respectively. Fluorescence was detected with bandpass emission filters: 420-480 nm for Hoechst and 560-605 nm for Cy3. The captured signals were recorded as blue and red, respectively.

\section{Flow cytometry}

Annexin/PI staining was performed using FITC Annexin V Apoptosis Detection Kit I (BD Biosciences, 556547). Briefly, spent medium was collected as much as possible from each well with cultured MGCs in a 6-well plate and was kept for future use. After being washed twice with cooled PBS, 200 $\mu \mathrm{L}$ of PBS containing $0.25 \%$ trypsin were added to each well. Digestion was carried out at $37^{\circ} \mathrm{C}$ for 3 to 4 min before termination by adding the spent medium collected previously. The MGCs were then dispersed by repeatedly pipetting in PBS, the resultant suspension was collected into a centrifuge tube and centrifuged at $200 \mathrm{~g}$ for $5 \mathrm{~min}$. After supernatant was removed, the cells were resuspended with cooled PBS and washed twice by centrifugation (200 $\mathrm{g}$ for $5 \mathrm{~min}$ ). Then, the cells were resuspended with $100 \mu \mathrm{L} 1 \times$ staining buffer, $5 \mu \mathrm{L}$ Annexin V-FITC, and $5 \mu \mathrm{L}$ PI staining solution and stained for $15 \mathrm{~min}$ at $37^{\circ} \mathrm{C}$ in darkness. At the end of staining, $400 \mu \mathrm{L} 1 \times$ staining buffer were added and the mixture was cooled on ice. The stained cells were subjected to flow cytometry (BD LSR Fortessa $^{\mathrm{TM}}$ ) within $1 \mathrm{~h}$ after staining to assess apoptosis. Data obtained were analyzed using Flowjo software (Flowjo 7.6 LLC, OR, USA). The cell populations were gated according to the gating information of non-dyed control cells and Annexin V- or Pl-dyed control cells.

\section{Transfection of MGCs with siRNAs}

The siRNAs targeting mRNAs and the negative control siRNA were designed and synthesized by RiboBio (Guangzhou, China). The sense strands of targeting siRNAs for the TNF- $\alpha$ gene included siRNA-1 (5'-GAC AAC CAA CTA GTG GTGC-3'), siRNA-2 (5'-CCA ACG GCA TGG ATC TCAA-3'), and siRRibo $^{\text {TM }}$ for negative control. Transfection with 100 nM siRNAs was performed using lipofectamine RNAiMAX reagent (Invitrogen/Life Technologies). Briefly, when cells grew to $50-60 \%$ of confluence, the spent medium in the wells was replaced by $90 \mu \mathrm{L}$ of fresh TCM-199 medium and the cells were transfected by the forward transfection method. Approximately
$0.5 \mu \mathrm{L}$ of a $20 \mu \mathrm{M}$ solution of each siRNA were diluted in $4.5 \mu \mathrm{L}$ of Opti-MEM medium (Invitrogen) and mixed with 0.3 $\mu \mathrm{L}$ of Lipofectamine RNAiMAX reagent (Invitrogen) diluted in $4.7 \mu \mathrm{L}$ of Opti-MEM medium. After incubation for $5 \mathrm{~min}$ at room temperature, the transfection complex was added to the wells and incubated for $48 \mathrm{~h}$ at $37^{\circ} \mathrm{C}$ in a humidified $5 \% \mathrm{CO}_{2}$ atmosphere.

\section{Real-time PCR}

The MGCs recovered from two TNF-/- or C57 mice were treated to extract RNA using the PicoPure RNA Isolation Kit (Applied Biosystems) with on-column DNase treatment (Qiagen). RT was performed in a total volume of $20 \mu \mathrm{L}$ using Transcriptor Reverse Transcriptase (Roche). Briefly, $2 \mu \mathrm{L}$ of each RNA sample was mixed in a $0.2 \mathrm{~mL}$ reaction tube with $1 \mu \mathrm{L}$ Oligo dT18 (Fermentas) and $10 \mu \mathrm{L}$ DEPC-dH2O and the mixture was incubated in a PCR instrument at $65^{\circ} \mathrm{C}$ for $10 \mathrm{~min}$. As soon as the incubation ended, the reaction tube was cooled on ice for $2 \mathrm{~min}$ and then centrifuged (200 $\mathrm{g}$ for $10 \mathrm{~s}$ at $4^{\circ} \mathrm{C}$ ) for a few seconds. Then, $4 \mu \mathrm{L}$ of $5 \times \mathrm{RT}$ buffer, $0.5 \mu \mathrm{L}$ RNase inhibitor (Roche), $2 \mu \mathrm{L} d$ NTP (Fermentas), and $0.5 \mu \mathrm{L}$ Transcriptor Reverse Transcriptase were added to the reaction tube. The mixture was then incubated at $55^{\circ} \mathrm{C}$ for 30 min, followed by incubation at $85^{\circ} \mathrm{C}$ for $5 \mathrm{~min}$ before stored at $-20^{\circ} \mathrm{C}$ until use.

Quantification of mRNA was conducted using the Mx3005P real-time PCR instrument (Stratagene). Amplification reactions were performed in a $10-\mu \mathrm{L}$ reaction volume containing $1 \mu \mathrm{L}$ of cDNA, $5 \mu \mathrm{L}$ of $2 \times$ SYBR Green Master Mix (Agilent), 0.15 $\mu \mathrm{L}$ of ROX (reference dye), $3.25 \mu \mathrm{L}$ RNase-free water, and $0.3 \mu \mathrm{L}$ each of forward and reverse gene-specific primers $(10 \mu \mathrm{M})$. Cycle amplification conditions comprised an initial denaturation step at $95^{\circ} \mathrm{C}$ for 3 min followed by 40 cycles at $95^{\circ} \mathrm{C}$ for $20 \mathrm{~s}$ and $60^{\circ} \mathrm{C}$ for $20 \mathrm{~s}$. Gene-specific primers used are as follows. For Gapdh, forward 5-AAG GTG GTG AAG CAG GCAT-3, reverse 5-GGT CCA GGG TTT CTT ACT CCT3; for $\mathrm{BCl}$-2, forward 5-TTC GGG ATG GAG TAA ACTGG3, reverse 5-TGG ATC CAA GGC TCT AGGTG-3; and for Bax, forward 5-TGC AGA GGA TGA TTG CTGAC-3, reverse 5-GAT CAG CTC GGG CAC TTTAG-3. Gene expression was normalized to the Gapdh internal control. All values were then expressed relative to calibrator samples using the $2^{-(\Delta \Delta C T)}$ method.

\section{Statistical analysis}

We repeated each treatment at least three times. Percentage data were arc sine transformed before being analyzed using one-way ANOVA when each measure contained more than two groups or using independent sample $t$-test when each measure had only two groups. We used Duncan multiple comparison test to locate differences during the ANOVA. We used Statistics Package for Social Science (SPSS 20, SPSS, Inc.) to conduct the analysis. We express data as means \pm S.E.M. and considered data significant when the $P$ value was less than 0.05 . 


\section{Results \\ Cortisol injection of female mice impaired oocyte developmental potential and mitochondrial membrane potential (MMP) with increased oxidative stress}

This experiment was conducted to examine the effects of cortisol injection of female mice on oocyte developmental potential and oxidative stress. At $24 \mathrm{~h}$ following cortisol injection, both cortisol- and ethanolinjected mice were killed to recover oocytes and the oocytes collected were either inseminated in vitro or used for assessment of reactive oxygen species (ROS) and mitochondrial membrane potential (MMP). While percentages of fertilized oocytes and 4-cell embryos did not differ, rates of blastocysts and cell number per blastocyst were significantly lower in oocytes recovered from cortisol-injected mice than from control mice injected with ethanol (Fig. 1A). While intra-oocyte ROS increased (Fig. 1B and D), MMP of oocytes decreased significantly (Fig. 1C and E) in cortisol-injected mice compared to that in the ethanol-injected mice. The results confirmed that cortisol injection of female mice significantly impaired oocyte developmental potential with increased oxidative stress.

\section{Cortisol injection of female mice induced apoptosis in MGCs with increased oxidative stress in the ovary}

To test whether cortisol injection increases oxidative stress and triggers apoptosis of ovarian cells, both cortisol- and ethanol-injected mice were killed to collect ovaries for assessment of apoptosis in MGCs and oxidative stress index (OSI) in the ovary. Our TUNEL analysis indicated that percentages of apoptotic MGCs were significantly higher in mice injected with cortisol than in control mice injected with ethanol (Fig. 2A and B). Total oxidative status (TOS) and OSI in both serum and ovarian homogenates were significantly higher in cortisol-injected mice than in control mice injected with alcohol (Fig. 2C and D). The results suggested that an elevation in cortisol triggered apoptosis of ovarian cells with increased oxidative stress.

\section{Cortisol injection of female mice activated the TNF- $\alpha$ system in ovaries and oocytes}

The purpose of this experiment was to observe whether cortisol injection of female mice would activate the TNF$\alpha$ system in ovaries. To this end, cortisol- and ethanolinjected mice were killed to collect blood and ovaries. First, TNF- $\alpha$ in serum and ovarian homogenates was measured by ELISA and TNFR1 in MGCs was assayed by Western blotting. The results showed that cortisol injection significantly increased expression of TNF- $\alpha$ in both serum and ovarian homogenates and expression of TNFR1 in MGCs compared to ethanol injection (Fig. $3 \mathrm{~A}$ and $\mathrm{B})$. The effects of cortisol injection on activation

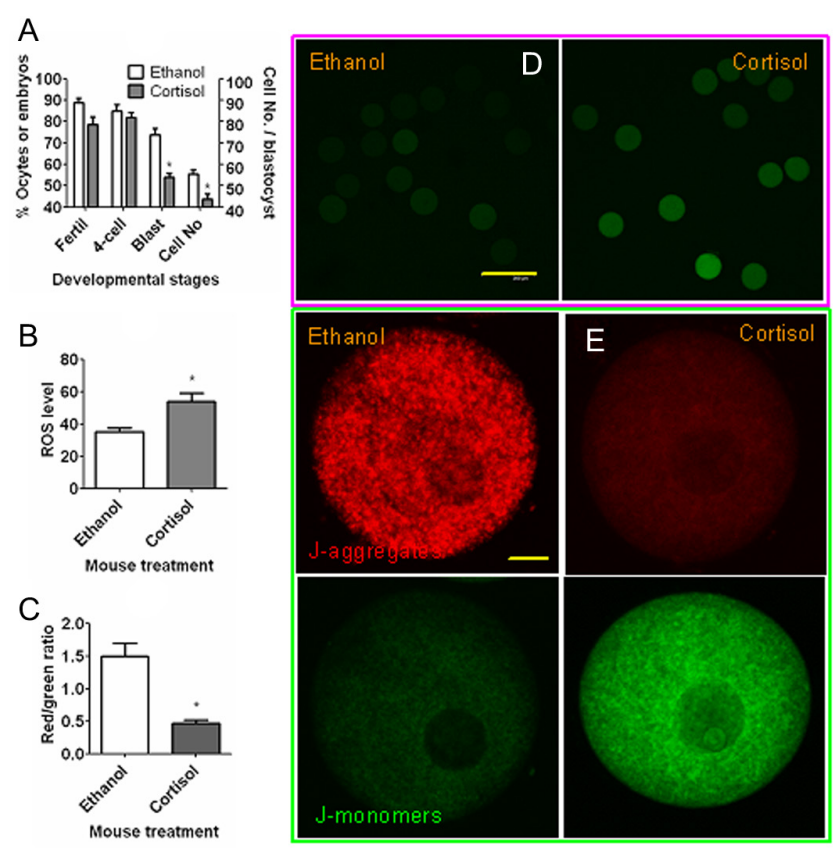

Figure 1 Effects of cortisol injection of female mice on oocyte developmental potential, redox state, and mitochondrial membrane potential (MMP). Germinal vesicle (GV) stage oocytes were recovered from mice that had been injected with ethanol or cortisol and were used for in vitro maturation or for observation of redox state and MMP. (A) Percentages of fertilized oocytes, 4-cell embryos, blastocysts, and cell number per blastocyst following in vitro maturation and insemination of GV oocytes. Each treatment was repeated 5-6 times with each replicate containing 20-30 oocytes inseminated with spermatozoa from the same male mouse. Percentages of fertilized oocytes, 4-cell embryos, and blastocysts were calculated from oocytes inseminated, fertilized oocytes, and 4-cell embryos, respectively. (B) Levels (fluorescence intensity values, FIV) of reactive oxygen species (ROS) in oocytes freshly recovered from ethanol- or cortisol-injected mice. (C) MMP (red/green fluorescence intensity) as determined by staining with MMP-specific probe $\mathrm{JC}-1$. In both graphs $\mathrm{B}$ and $\mathrm{C}$, each treatment was repeated three times with each replicate containing 20 oocytes. * indicates significant difference $(P<0.05)$ from values of oocytes from ethanol-injected mice. (D) Confocal images showing the FIV of ROS in oocytes from ethanol- or cortisol-injected mice. Bar is $200 \mu \mathrm{m}$. (E) Confocal images showing JC-1 staining intensity in oocytes from ethanol- or cortisol-injected mice. The same oocyte from ethanol- or cortisol-injected mice was observed either in TRITC channel (showing JC-1 aggregates of red fluorescence in the upper row) or in FITC channel (showing JC-1 monomers of green fluorescence in the lower row). Bar is $15 \mu \mathrm{m}$.

of the TNF- $\alpha$ system in oocytes were then observed. To quantify oocyte expression of TNF- $\alpha$ and TNFR, TNF$\alpha$ in medium conditioned by oocytes were measured by ELISA and TNFR1 in oocytes were quantified by immunofluorescence microscopy. Levels of both TNF$\alpha$ (Fig. 3C) and TNFR1 (Fig. 3D, E, F and G) were significantly higher in oocytes from cortisol-injected mice than in oocytes from ethanol-injected mice. The results suggested that cortisol elevation significantly activated the TNF- $\alpha$ signaling in both ovaries and oocytes. 

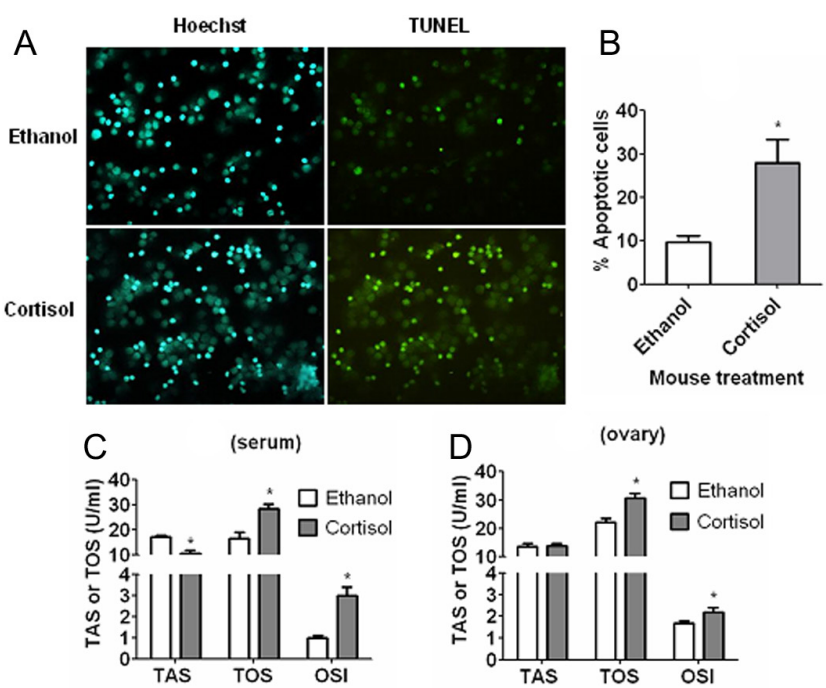

Figure 2 Apoptosis in mural granulosa cells (MGCs) and oxidative stress in the ovary after cortisol injection of female mice. Panel A shows images when smears of MGCs from ethanol- and cortisolinjected mice were observed under a fluorescence microscope following Hoechst and TUNEL staining. Original magnification: 400×. Graph B shows percentages of apoptotic cells revealed by TUNEL. Graphs C and D show levels of TAS, TOS, and oxidative index (OSI) in serum and ovarian homogenates, respectively, from mice injected with ethanol or cortisol. Each treatment was repeated nine times with each replicate including serum or ovarian homogenates from a single (the same) mouse. The OSI was calculated as follows: $\mathrm{OSI}=\mathrm{TOS} / \mathrm{TAS} . *$ indicates significant difference $(P<0.05)$ from the control (ethanol) values.

\section{Culture of MGCs with corticosterone induced apoptosis and activated the TNF- $\alpha$ system}

An in vitro experiment was conducted to further verify the effects of glucocorticoids on apoptosis and TNF- $\alpha$ activation of ovarian cells. At $48 \mathrm{~h}$ after eCG injection, mice were killed without cortisol or ethanol injection to collect ovaries. The MGCs recovered were cultured in DMEM/F12 medium containing corticosterone alone or with glucocorticoid receptor antagonist, RU486, before examination for apoptosis by flow cytometry, for TNF$\alpha$ expression by ELISA, and for TNFR1 expression by Western blotting. The results showed that corticosterone significantly increased the percentage of apoptotic MGCs and expression of both TNF- $\alpha$ and TNFR1 and that RU486 completely reversed the pro-apoptotic effects of corticosterone to the level in control MGCs cultured in DMEM/F12 medium alone (Fig. 4). The results further confirmed that glucocorticoids triggered apoptosis and activated the TNF- $\alpha$ signaling in ovarian cells.

\section{Knockdown or knockout of TNF- $\alpha$ significantly ameliorated the pro-apoptotic effects of glucocorticoids on oocytes and MGCs}

Two experiments were conducted to verify that glucocorticoids induce apoptosis of oocytes and ovarian
A

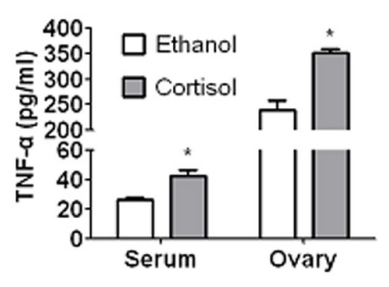

C
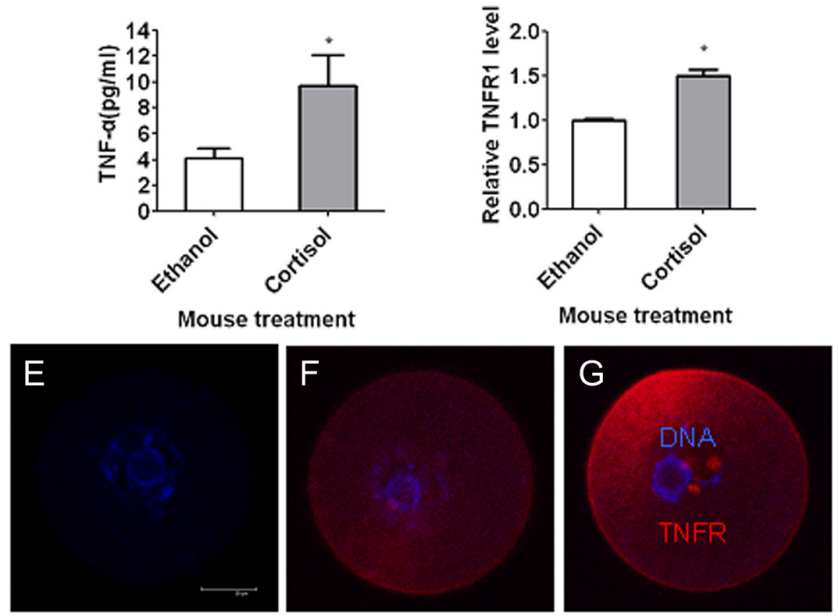

Figure 3 Activation of the TNF- $\alpha$ system in ovaries and oocytes following cortisol injection of female mice. Female mice were injected with eCG and, $24 \mathrm{~h}$ later, the mice were injected with ethanol or cortisol. At $24 \mathrm{~h}$ after ethanol/cortisol injection, the mice were killed to collect serum and ovaries/MGCs/oocytes. Graph A shows ELISA measurement of TNF- $\alpha$ in serum and ovarian homogenates from ethanol- or cortisol-injected mice. Each treatment was repeated three times with each replicate including three mice. Graph B shows Western blot results of TNFR1 expression in MGCs from ethanol- and cortisol-injected mice. Each treatment was repeated three times with each replicate containing two mice. Graph $C$ shows ELISA-measured TNF- $\alpha$ levels in medium conditioned for 14 $\mathrm{h}$ by GV oocytes from ethanol- and cortisol-injected mice in TCM-199 without SGH. Each treatment was repeated seven times with each replicate including $100 \mu \mathrm{L}$ medium conditioned by 30 oocytes. Graph D shows relative level of TNFR1/GAPDH (fluorescence intensity value) calculated from confocal microscopic images. * indicates significant difference $(P<0.05)$ from values of oocytes from ethanol-injected mice. Panels E, F, and G are merged laser confocal images showing negative control, ethanol-, and cortisol-treated oocytes, respectively. DNA and TNFR1 are colored blue and red, respectively. Bar is $20 \mu \mathrm{m}$.

cells through activating the TNF- $\alpha$ system. In the first experiment, mice were killed at $48 \mathrm{~h}$ after eCG injection without cortisol or ethanol injection to collect ovaries. Expression of the TNF- $\alpha$ gene in MGCs was knocked down by transfection with TNF- $\alpha$ siRNAs. To evaluate the silencing efficiency of different siRNA sequences, TNF- $\alpha$ levels in the transfected cells were measured by ELISA. The ELISA results showed that the MGCs transfected with TNF- $\alpha$ siRNA- 1 expressed significantly less TNF- $\alpha$ than MGCs transfected with negative control (NC) siRNA did (Fig. 5A). Then, the transfected MGCs were incubated 

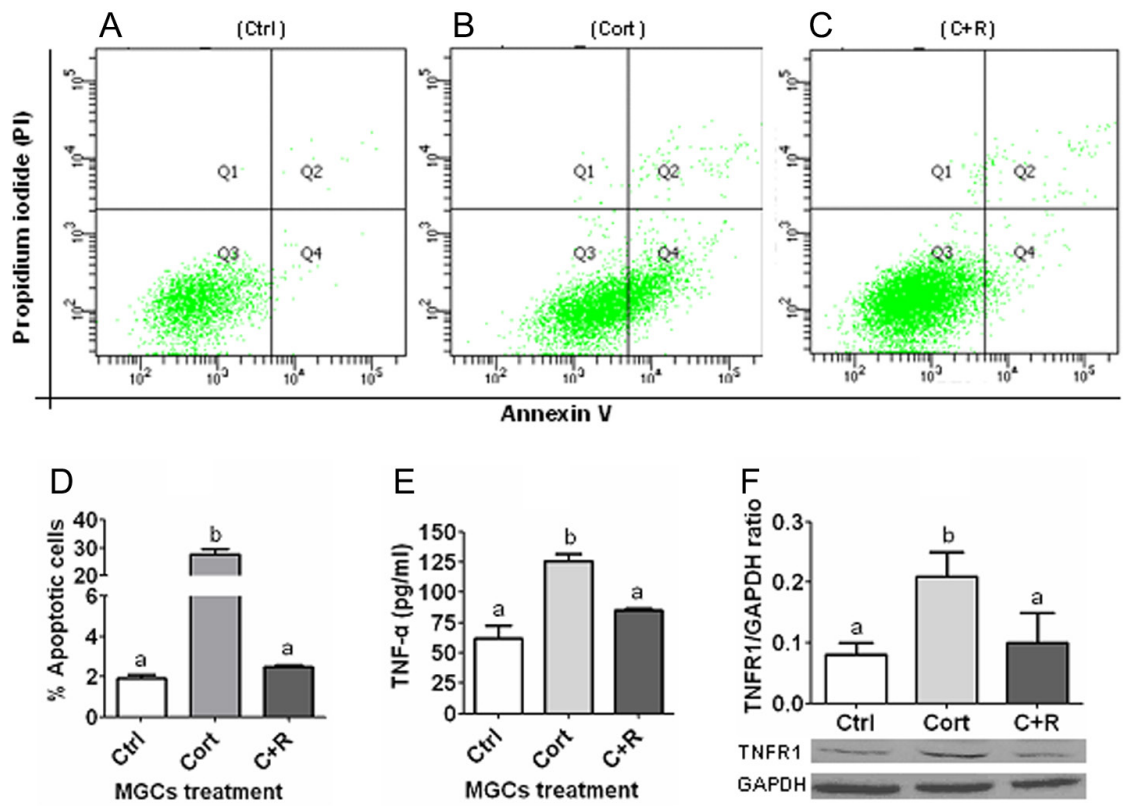

Figure 4 Levels of apoptosis, TNF- $\alpha$, and TNFR1 following culture of MGCs with corticosterone. MGCs were recovered from unstressed mice and cultured in DMEM/F12 medium. When growing to $70-80 \%$ confluence, the cells were changed into DMEM/F12 alone (Ctrl), or with $10^{-5} \mathrm{M}$ corticosterone (Cort) or Cort and $10^{-5} \mathrm{M}$ RU486 $(\mathrm{C}+\mathrm{R})$, and cultured for $24 \mathrm{~h}$ before examination for apoptosis and expression of TNF- $\alpha$ and TNFR1. Panels A, B, and C show flow cytometry graphs following annexin- $\mathrm{V}$ and Pl staining of MGCs in Ctrl, Cort, and $\mathrm{C}+\mathrm{R}$ groups, respectively. While almost all of the cells are in the Q3 area in the Ctrl and $\mathrm{C}+\mathrm{R}$ groups, quite a few cells are located in the Q4 and Q2 areas in the Cort-treated cells, indicating that, significantly, more cells underwent early or late apoptosis after Cort treatment and that RU486 treatment completely counteracted the pro-apoptotic effect by Cort. Graphs D and E show percentages of apoptotic cells revealed by flow cytometry and the TNF- $\alpha$ levels measured by ELISA, respectively, in MGCs in Ctrl, Cort, or $\mathrm{C}+\mathrm{R}$ treatment groups. Each treatment was repeated three times with each replicate containing MGCs from one well of a 6 -well culture plate. Graph F shows relative levels of TNFR1 expression detected by Western blotting in MGCs after different treatments. Each treatment was repeated three times with each replicate including MGCs from one well of a 12-well culture plate. a,b: Values with a different letter above bars differ significantly $(P<0.05)$. with corticosterone before assessment of apoptosis by flow cytometry. Our flow cytometry indicated that transfection with TNF- $\alpha$ siRNA-1 significantly decreased the percentage of apoptotic MGCs compared to transfection with NC siRNA (Fig. 5B, C and D).

In the second experiment, TNF-/- and WT mice with a C57BL/6J genetic background were injected with cortisol or ethanol before recovery of oocytes and MGCs for analysis of oocyte developmental potential and MGC apoptosis, respectively. Analysis of oocyte competence demonstrated that rates of oocyte maturation and activation did not differ among treatments. Percentages of 4-cell embryos/activated oocytes and blastocysts/4cell embryos did not differ between WT and TNF-/mice following ethanol injection (Fig. 5E). Although cortisol injection significantly decreased the rates of blastocysts in both WT and TNF-/- mice, blastocyst rates were significantly higher in TNF-/- mice than in WT mice, suggesting that TNF- $\alpha$ knockout significantly relieved the adverse effects of cortisol injection on oocyte developmental potential. Similarly, our real-time PCR quantification showed that the level of $\mathrm{Bcl} 2 / \mathrm{Bax}$ ratio in MGCs was significantly higher in TNF-/- mice than in WT mice after injection with cortisol (Fig. 5F), suggesting again that TNF- $\alpha$ knockout significantly relieved the pro-apoptotic effects of cortisol injection on cells. In summary, our TNF- $\alpha$ knockdown and knockout experiments further confirmed that glucocorticoids induced apoptosis of oocytes and ovarian cells through activating the TNF- $\alpha$ system.

\section{Corticosterone treatment showed different effects on TNF- $\alpha$ expression between MGCs and oviductal epithelial cells}

Because we found many papers reporting that glucocorticoids inhibit rather than increase TNF- $\alpha$ expression, which was in conflict with our results, we compared effects of corticosterone treatment on TNF- $\alpha$ expression between MGCs and oviductal cells. At $48 \mathrm{~h}$ after eCG injection, mice were killed without cortisol or ethanol injection to collect ovaries and oviducts. The monolayers of MGCs and oviductal epithelial cells were cultured for $24 \mathrm{~h}$ in DMEM/F12 medium with or without $10^{-5} \mathrm{M}$ corticosterone before ELISA measurement for TNF- $\alpha$ concentrations. While the TNF- $\alpha$ level was significantly increased in MGCs, it was significantly decreased in oviductal epithelial cells following 

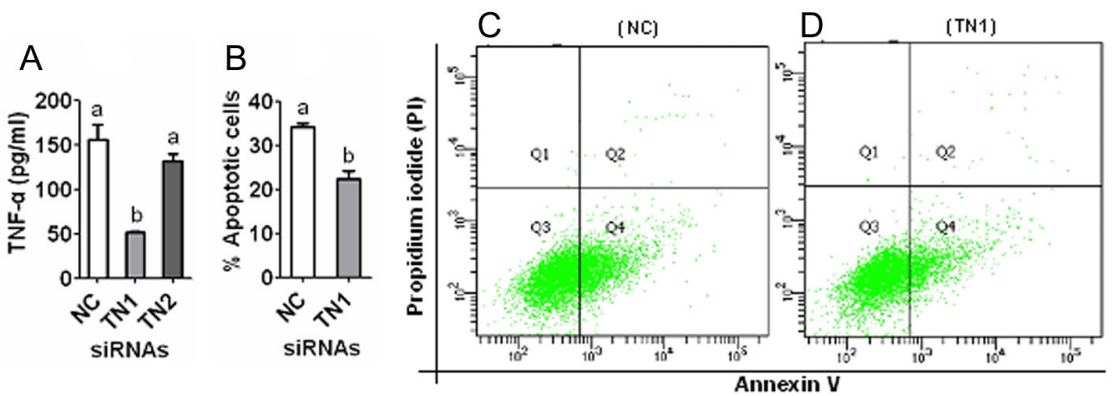

Figure 5 Effects of knocking down or knocking out TNF- $\alpha$ on the pro-apoptotic effects of glucocorticoids on oocytes and MGCs. Graphs $\mathrm{A}$ and $\mathrm{B}$ show concentrations of TNF- $\alpha$ and percentages of apoptotic cells, respectively, after MGCs were transfected with negative control (NC), TNF- $\alpha$ siRNA-1 (TN1), or TNF- $\alpha$ siRNA-2 (TN2). TNF- $\alpha$ was measured by ELISA, and percentages of apoptotic cells (Q2+Q4) were measured by flow cytometry, after the transfected MGCs were challenged with corticosterone. Each treatment was repeated three times with each replicate containing MGCs from one well of a 6-well culture plate. Panels $C$ and D show flow cytometry graphs following annexin- $\mathrm{V}$ and $\mathrm{PI}$ staining of MGCs in NC and TN1 groups, respectively. Graph E shows percentages of activated oocytes (Act), 4-cell (4-C), and blastocyst (Blast) embryos after WT or TNF-/mice were injected with ethanol (E) or cortisol
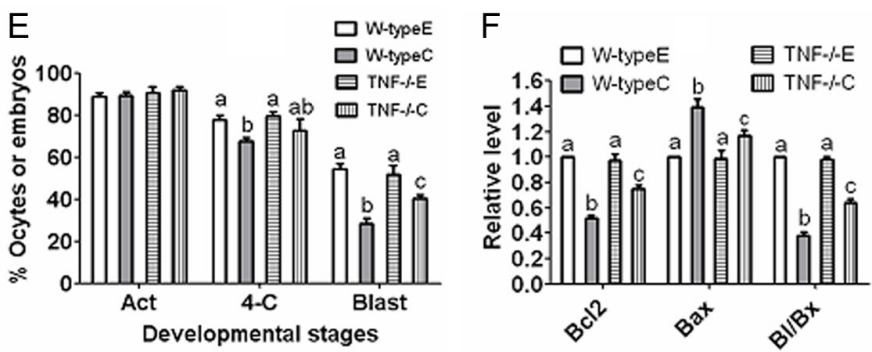
(C). Each treatment was repeated four times with each replicate containing about 20 oocytes from two mice. Graph $\mathrm{F}$ shows relative level of $\mathrm{BCl} 2$ and $\mathrm{Bax}$ and $\mathrm{BCl} / \mathrm{Bax}$ $(\mathrm{Bl} / \mathrm{Bx})$ ratio in MGCs after WT or TNF-/- mice were injected with ethanol (E) or cortisol (C). Each treatment was repeated three times with each replicate containing MGCs from three mice. a-c: Values without a common letter above bars differ significantly $(P<0.05)$.

corticosterone treatment (Fig. 6). The results suggested that the effect of glucocorticoids on TNF- $\alpha$ expression might vary between cell types.

\section{Discussion}

Both our in vivo and in vitro experiments showed that glucocorticoids induced apoptosis in MGCs and oocytes. Thus, injection of female mice with $50 \mathrm{mg} /$ $\mathrm{kg}$ of cortisol, which increased serum cortisol to a restraint-induced level $\left(1.4 \times 10^{-7} \mathrm{M}\right.$, Yuan et al. 2016), significantly impaired developmental potential of oocytes and induced apoptosis in MGCs while increasing oxidative stress. Culture with corticosterone $\left(10^{-5} \mathrm{M}\right)$ triggered apoptosis in MGCs. There are many reports that glucocorticoids can induce cell apoptosis (Tuckermann et al. 2005). For example, treatment of mice with 7 or $10 \mathrm{mg} / \mathrm{kg}$ of dexamethasone significantly increased apoptotic indexes in testicular germ cells (Khorsandi et al. 2008). Culture with dexamethasone $\left(10^{-6} \mathrm{M}\right)$ induced apoptosis with activation of the Fas/ FasL system in monocytes (Schmidt et al. 2001) and osteocytes (Kogianni et al. 2004). Furthermore, it is well known that glucocorticoids can induce apoptosis in $\mathrm{T}$ lymphocytes (Herold et al. 2006).

The present results showed that glucocorticoids impaired oocyte competence and triggered apoptosis in MGCs with increased oxidative stress. Thus, cortisol injection of female mice impaired oocyte

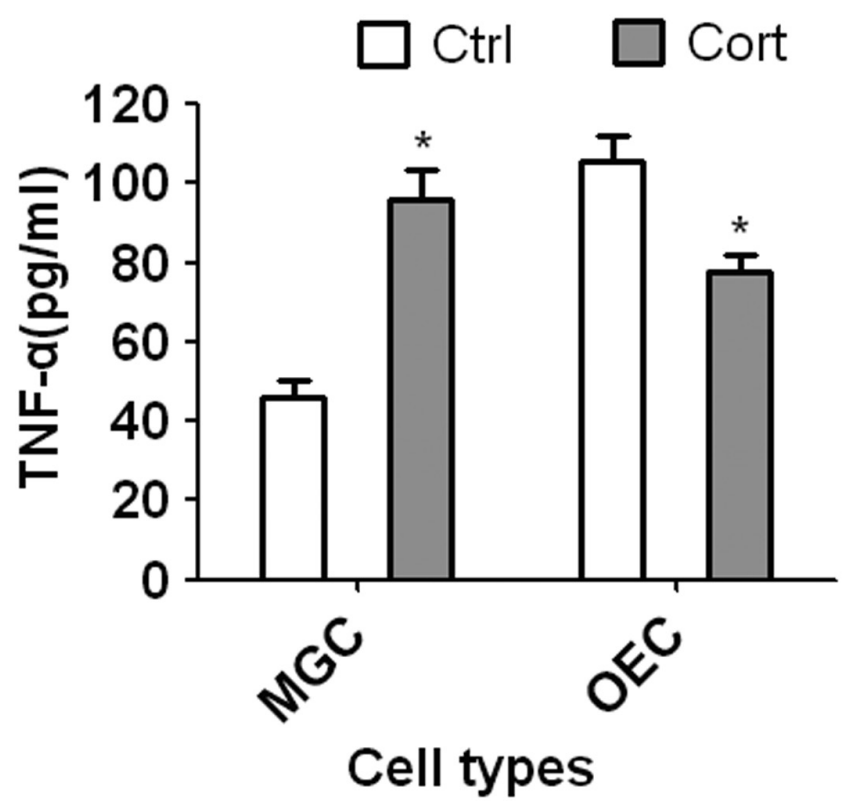

Figure 6 Effects of corticosterone treatment on TNF- $\alpha$ expression in MGCs and oviductal epithelial cells (OECs). Monolayers of MGCs and oviductal epithelial cells were cultured for $24 \mathrm{~h}$ in DMEM/F12 medium with (Cort) or without (Ctrl) $10^{-5} \mathrm{M}$ corticosterone before ELISA measurement for TNF- $\alpha$ concentrations. Each treatment was repeated three times with each replicate including OECs from one well of a 6 -well plate. ${ }^{*}$ indicates significant difference $(P<0.05)$ from values of control groups. 
developmental potential and mitochondrial membrane potential and induced apoptosis in MGCs, both with increased oxidative stress. It has been reported that glucocorticoids can induce cell apoptosis by increasing oxidative stress. For example, glucocorticoids induced apoptosis of lymphocytes by reducing mitochondrial membrane potential and generating reactive oxygen species (ROS) (Zamzami et al. 1995). Treatment with dexamethasone and TNF- $\alpha$ promoted ROS production and apoptosis in osteoblasts (Almeida et al. 2011). Furthermore, treatment with betulinic acid or selenium decreased dexamethasone-induced apoptosis in mouse thymocytes (Yi et al. 2016) and in human osteoblast-like cell line (Yazıcı et al. 2018), respectively, by reducing oxidative stress.

However, because there are reports that agents that reduce the mitochondrial potential (e.g. uncouplers) may decrease ROS production as well (Toime \& Brand 2010, Mailloux \& Harper 2011), our results that cortisol injection reduced mitochondrial potential while increasing ROS require some explanations. There is evidence that the mitochondrial ROS is critical in initiating mitochondrial inner membrane permeabilization and mitochondrial swelling. For example, Peng and Jou (2004) observed that, in cells exposed to radiation, the intracellular ROS first increased, and then, swelling, which indicates the opening of the mitochondrial permeability transition pore, was observed in mitochondria that contained higher levels of ROS. When the mitochondrial ROS reached the highest level, a complete loss of mitochondrial membrane potential was observed. Furthermore, Lam et al. (2001) also reported that the formation of mitochondrial ROS was followed by inner membrane permeabilization, depolarization, and swelling of mitochondria.

This study demonstrated that glucocorticoids impaired oocyte competence and triggered apoptosis in ovarian cells through activating the TNF- $\alpha$ system. Thus, cortisol injection of female mice activated the TNF- $\alpha$ system in both ovaries and oocytes. Culture with corticosterone induced apoptosis and activated the TNF$\alpha$ system in MGCs. Knockdown or knockout of TNF- $\alpha$ significantly ameliorated the pro-apoptotic effects of glucocorticoids on oocytes and MGCs. Despite of great efforts, however, we could retrieve fewer papers reporting that glucocorticoids upregulate the TNF$\alpha$ signaling (Dinkel et al. 2003) than papers reporting that glucocorticoids inhibit TNF- $\alpha$-induced apoptosis and TNF- $\alpha$ expression (Messmer et al. 2001, Zhang et al. 2001). We therefore conducted experiments to clarify this conflict. Monolayers of MGCs and oviductal epithelial cells were cultured for $24 \mathrm{~h}$ in DMEM/F12 medium with or without corticosterone before ELISA measurement for TNF- $\alpha$ concentrations. The results showed that, while TNF- $\alpha$ expression was increased in MGCs, it was decreased significantly in oviductal epithelial cells following corticosterone treatment, suggesting that the effect of glucocorticoids on TNF- $\alpha$ expression might vary between cell types.

In summary, by both in vivo and in vitro experiments, we have studied the mechanisms by which glucocorticoids impair oocyte competence. The results demonstrated that in vivo and/or in vitro exposure to glucocorticoids significantly impaired oocyte competence and triggered apoptosis in MGCs with increased oxidative stress and enhanced TNF- $\alpha$ and TNFR expression. In vitro TNF- $\alpha$ knockdown by RNAi or in vivo knockout of TNF- $\alpha$ significantly relieved the adverse effects of glucocorticoids on oocytes and MGCs. However, in vitro exposure to glucocorticoids downregulated TNF$\alpha$ expression significantly in oviductal epithelial cells. In conclusion, our results suggested that glucocorticoids impaired oocyte competence and triggered apoptosis in ovarian cells through activating the TNF- $\alpha$ system and that the effect of glucocorticoids on TNF- $\alpha$ expression might vary between cell types. The data are not only important for our understanding of the mechanisms by which stress impairs reproduction, but also relevant for our understanding of the role of glucocorticoids in the regulation of the inflammatory responses, as we have shown that the effect of glucocorticoids on TNF- $\alpha$ expression may vary between cell types.

\section{Declaration of interest}

The authors declare that there is no conflict of interest that could be perceived as prejudicing the impartiality of the research reported.

\section{Funding}

This study was supported by grants from the National Key R\&D Program of China (Nos. 2017YFC1001601, 2017YFC1001602, and 2017YFD0501904), the China National Natural Science Foundation (Nos. 31702114 and 31772599), the Natural Science Foundation of Shandong Province (No. ZR2017BC025), and the Funds of Shandong Double Tops Program (No. SYL2017YSTD12).

\section{Author contribution statement}

H J Y, Z B L, X Y Z, G Y S, G L W, Y Q Z, and M Z conducted the experiments. H J Y, Z B L, and J H T analyzed the data. J $\mathrm{H} \mathrm{T}$ designed the experiments and wrote the manuscript. All authors reviewed the manuscript.

\section{References}

Almeida M, Han L, Ambrogini E, Weinstein RS \& Manolagas SC 2011 Glucocorticoids and tumor necrosis factor $\alpha$ increase oxidative stress and suppress Wnt protein signaling in osteoblasts. Journal of Biological Chemistry 286 44326-44335. (https://doi.org/10.1074/jbc. M111.283481)

Andersen CY 2003 Effect of glucocorticoids on spontaneous and folliclestimulating hormone induced oocyte maturation in mouse oocytes 
during culture. Journal of Steroid Biochemistry and Molecular Biology 85 423-427. (https://doi.org/10.1016/s0960-0760(03)00190-0)

Csemiczky G, Landgren BM \& Collins A 2000 The influence of stress and state anxiety on the outcome of IVF-treatment psychological and endocrinological assessment of Swedish women entering IVF-treatment. Acta Obstetricia et Gynecologica Scandinavica 79 113-118. (https://doi. org/10.1034/j.1600-0412.2000.079002113.x)

Deb GK, Dey SR, Bang JI, Cho SJ, Park HC, Lee JG \& Kong IK 2011 9-cis retinoic acid improves developmental competence and embryo quality during in vitro maturation of bovine oocytes through the inhibition of oocyte tumor necrosis factor- $\alpha$ gene expression. Journal of Animal Science 89 2759-2767. (https://doi.org/10.2527/jas.2011-3848)

Dinkel K, MacPherson A \& Sapolsky RM 2003 Novel glucocorticoid effects on acute inflammation in the CNS. Journal of Neurochemistry $\mathbf{8 4}$ 705-716. (https://doi.org/10.1046/j.1471-4159.2003.01604.x)

Gao HB, Tong MH, Hu YQ, You HY, Guo QS, Ge RS \& Hardy MP 2003 Mechanisms of glucocorticoid-induced Leydig cell apoptosis. Molecular and Cellular Endocrinology 199 153-163. (https://doi.org/10.1016/ s0303-7207(02)00290-3)

Glavin GB, Paré WP, Sandbak T, Bakke HK \& Murison R 1994 Restraint stress in biomedical research: an update. Neuroscience and Biobehavioral Reviews 18 223-249. (https://doi.org/10.1016/0149-7634(94)90027-2)

Gong S, Miao YL, Jiao GZ, Sun MJ, Li H, Lin J, Luo MJ \& Tan JH 2015 Dynamics and correlation of serum cortisol and corticosterone under different physiological or stressful conditions in mice. PLOS ONE 10 e0117503. (https://doi.org/10.1371/journal.pone.0117503)

González R, Ruiz-León Y, Gomendio M \& Roldan ER 2010 The effect of glucocorticoids on mouse oocyte in vitro maturation and subsequent fertilization and embryo development. Toxicology In Vitro 24 108-115. (https://doi.org/10.1016/j.tiv.2009.08.025)

Greenfeld CR, Roby KF, Pepling ME, Babus JK, Terranova PF \& Flaws JA 2007 Tumor necrosis factor (TNF) receptor type 2 is an important mediator of TNF alpha function in the mouse ovary. Biology of Reproduction 76 224-231. (https://doi.org/10.1095/biolreprod.106.055509)

Herold MJ, McPherson KG \& Reichardt HM 2006 Glucocorticoids in T cell apoptosis and function. Cellular and Molecular Life Sciences 63 60-72. (https://doi.org/10.1007/s00018-005-5390-y)

Ihsanullah, Qureshi MS, Suhail SM, Akhtar S \& Khan RU 2017 Postpartum endocrine activities, metabolic attributes and milk yield are influenced by thermal stress in crossbred dairy cows. International Journal of Biometeorology 61 1561-1569. (https://doi.org/10.1007/s00484-0171335-z)

Kavurma MM, Tan NY \& Bennett MR 2008 Death receptors and their ligands in atherosclerosis. Arteriosclerosis, Thrombosis, and Vascular Biology 28 1694-1702. (https://doi.org/10.1161/ATVBAHA.107.155143)

Kee BS, Jung BJ \& Lee SH 2000 A study on psychological strain in IVF patients. Journal of Assisted Reproduction and Genetics 17 445-448. (https://doi.org/10.1023/a:1009417302758)

Khorsandi LS, Hashemitabar M, Orazizadeh M \& Albughobeish N 2008 Dexamethasone effects on Fas ligand expression in mouse testicular germ cells. Pakistan Journal of Biological Sciences 11 2231-2236. (https://doi.org/10.3923/pjbs.2008.2231.2236)

Kim JY, Kang HH, Ahn JH \& Chung JW 2008 Circadian changes in serum corticosterone levels affect hearing in mice exposed to noise. NeuroReport 19 1373-1376. (https://doi.org/10.1097/WNR.0b013e32830e4c1d)

Klonoff-Cohen H, Chu E, Natarajan L \& Sieber W 2001 A prospective study of stress among women undergoing in vitro fertilization or gamete intrafallopian transfer. Fertility and Sterility 76 675-687. (https://doi. org/10.1016/s0015-0282(01)02008-8)

Kogianni G, Mann V, Ebetino F, Nuttall M, Nijweide P, Simpson H \& Noble B 2004 Fas/CD95 is associated with glucocorticoid-induced osteocyte apoptosis. Life Sciences 75 2879-2895. (https://doi. org/10.1016/j.Ifs.2004.04.048)

Lam M, Oleinick NL \& Nieminen AL 2001 Photodynamic therapyinduced apoptosis in epidermoid carcinoma cells. Reactive oxygen species and mitochondrial inner membrane permeabilization. Journal of Biological Chemistry 276 47379-47386. (https://doi.org/10.1074/jbc. M107678200)

Li CY, Li ZB, Kong QQ, Han X, Xiao B, Li X, Chang ZL \& Tan JH 2018 Restraint-induced corticotrophin-releasing hormone elevation triggers apoptosis of ovarian cells and impairs oocyte competence via activation of the Fas/FASL system. Biology of Reproduction 99 828-837. (https:// doi.org/10.1093/biolre/ioy091)

Liang B, Wei DL, Cheng YN, Yuan HJ, Lin J, Cui XZ, Luo MJ \& Tan JH 2013 Restraint stress impairs oocyte developmental potential in mice role of $\mathrm{CRH}$-induced apoptosis of ovarian cells. Biology of Reproduction 8964. (https://doi.org/10.1095/biolreprod.113.110619)

MacNiven E, deCatanzaro D \& Younglai EV 1992 Chronic stress increases estrogen and other steroids in inseminated rats. Physiology and Behavior 52 159-162. (https://doi.org/10.1016/0031-9384(92)90446-9)

Mailloux RJ \& Harper ME 2011 Uncoupling proteins and the control of mitochondrial reactive oxygen species production. Free Radical Biology and Medicine 51 1106-1115. (https://doi.org/10.1016/j. freeradbiomed.2011.06.022)

Marcinkiewicz JL, Balchak SK \& Morrison LJ 2002 The involvement of tumor necrosis factor-alpha (TNF) as an intra-ovarian regulator of oocyte apoptosis in the neonatal rat. Frontiers in Bioscience-Landmark 7 d1997d2005. (https://doi.org/10.2741/A894)

Mazlomi A, Golbabaei F, Farhang Dehghan S, Abbasinia M, Mahmoud Khani S, Ansari M \& Hosseini M 2017 The influence of occupational heat exposure on cognitive performance and blood level of stress hormones a field study report. International Journal of Occupational Safety and Ergonomics 23 431-439. (https://doi.org/10.1080/1080354 8.2016.1251137)

Messmer UK, Pereda-Fernandez C, Manderscheid M \& Pfeilschifter J 2001 Dexamethasone inhibits TNF-alpha-induced apoptosis and IAP protein downregulation in MCF-7 cells. British Journal of Pharmacology 133 467-476. (https://doi.org/10.1038/sj.bjp.0704093)

Naz RK, Zhu X \& Menge AC 1997 Expression of tumor necrosis factoralpha and its receptors type I and type II in human oocytes. Molecular Reproduction and Development 47 127-133. (https://doi.org/10.1002/ (SICl)1098-2795(199706)47:2<127::AID-MRD1>3.0.CO;2-O)

Neggers Y, Goldenberg R, Cliver S \& Hauth J 2006 The relationship between psychosocial profile, health practices, and pregnancy outcomes. Acta Obstetricia and Gynecologica Scandinavica 85 277-285. (https://doi. org/10.1080/00016340600566121)

Paré WP \& Glavin GB 1986 Restraint stress in biomedical research: a review. Neuroscience and Biobehavioral Reviews 10 339-370. (https:// doi.org/10.1016/0149-7634(86)90017-5)

Peng TI \& Jou MJ 2004 Mitochondrial swelling and generation of reactive oxygen species induced by photoirradiation are heterogeneously distributed. Annals of the New York Academy of Sciences 1011 112-122. (https://doi.org/10.1007/978-3-662-41088-2_12)

Roth Z 2017 Effect of heat stress on reproduction in dairy cows: insights into the cellular and molecular responses of the oocyte. Annual Review of Animal Biosciences 5 151-170. (https://doi.org/10.1146/annurevanimal-022516-022849)

Schmidt M, Lügering N, Lügering A, Pauels HG, Schulze-Osthoff K, Domschke W \& Kucharzik T 2001 Role of the CD95/CD95 ligand system in glucocorticoid-induced monocyte apoptosis. Journal of Immunology 166 1344-1351. (https://doi.org/10.4049/ jimmunol.166.2.1344)

Schröder AK, Katalinic A, Diedrich K \& Ludwig M 2004 Cumulative pregnancy rates and drop-out rates in a German IVF programme: 4102 cycles in 2130 patients. Reproductive Biomedicine Online 8 600-606. (https://doi.org/10.1016/s1472-6483(10)61110-8)

Silva AWB, Ribeiro RP, Menezes VG, Barberino RS, Passos JRS, Dau AMP, Costa JJN, Melo LRF, Bezerra FTG, Donato MAM et al. 2017 Expression of TNF- $\alpha$ system members in bovine ovarian follicles and the effects of TNF- $\alpha$ or dexamethasone on preantral follicle survival, development and ultrastructure in vitro. Animal Reproduction Science 182 56-68. (https:// doi.org/10.1016/j.anireprosci.2017.04.010)

Soto P, Natzke RP \& Hansen PJ 2003 Actions of tumor necrosis factoralpha on oocyte maturation and embryonic development in cattle. American Journal of Reproductive Immunology 50 380-388. (https://doi. org/10.1034/j.1600-0897.2003.00101.x)

Sugino N, Nakamura Y, Okuno N, Shimamura K, Teyama T, Ishimatsu M \& Kato H 1994 Effects of restraint stress on luteal function in rats during mid-pregnancy. Journal of Reproduction and Fertility 101 23-26. (https:// doi.org/10.1530/jrf.0.1010023)

Toime LJ \& Brand MD 2010 Uncoupling protein-3 lowers reactive oxygen species production in isolated mitochondria. Free Radical 
Biology and Medicine 49 606-611. (https://doi.org/10.1016/j. freeradbiomed.2010.05.010)

Tuckermann JP, Kleiman A, McPherson KG \& Reichardt HM 2005 Molecular mechanisms of glucocorticoids in the control of inflammation and lymphocyte apoptosis. Critical Reviews in Clinical Laboratory Sciences 42 71-104. (https://doi. org/10.1080/10408360590888983)

Wiebold JL, Stanfield PH, Becker WC \& Hillers JK 1986 The effect of restraint stress in early pregnancy in mice. Journal of Reproduction and Fertility 78 185-192. (https://doi.org/10.1530/jrf.0.0780185)

Xiao B, Li X, Feng XY, Gong S, Li ZB, Zhang J, Yuan HJ \& Tan JH 2019 Restraint stress of male mice induces apoptosis in spermatozoa and spermatogenic cells: role of the FASL/Fas system. Biology of Reproduction 101 235-247. (https://doi.org/10.1093/biolre/ioz057)

Yazıcı T, Koçer G, Nazıroğlu M, Övey Ís \& Öz A 2018 Zoledronic acid, bevacizumab and dexamethasone-induced apoptosis, mitochondrial oxidative stress, and calcium signaling are decreased in human osteoblast-like cell line by selenium treatment. Biological Trace Element Research 184 358-368. (https://doi.org/10.1007/s12011-017-1187-8)

Yi J, Zhu R, Wu J, Wu J, Xia W, Zhu L, Jiang W, Xiang S \& Tan Z 2016 In vivo protective effect of betulinic acid on dexamethasone induced thymocyte apoptosis by reducing oxidative stress. Pharmacological Reports 68 95-100. (https://doi.org/10.1016/j.pharep.2015.07.003)

Yin YY, Ming L, Zheng LF, Kan HW, Li CR \& Li WP 2007 Bioactive compounds from Paecilomyces tenuipes regulating the function of the hypothalamo-hypophyseal system axis in chronic unpredictable stress rats. Chinese Medical Journal 120 1088-1092. (https://doi. org/10.1097/00029330-200706020-00011)

Yuan HJ, Han X, He N, Wang GL, Gong S, Lin J, Gao M \& Tan JH 2016 Glucocorticoids impair oocyte developmental potential by triggering apoptosis of ovarian cells via activating the Fas system. Scientific Reports 6 24036. (https://doi.org/10.1038/srep24036)

Zamzami N, Marchetti P, Castedo M, Decaudin D, Macho A, Hirsch T, Susin SA, Petit PX, Mignotte B \& Kroemer G 1995 Sequential reduction of mitochondrial transmembrane potential and generation of reactive oxygen species in early programmed cell death. Journal of Experimental Medicine 182 367-377. (https://doi.org/10.1084/jem.182.2.367)

Zhang HH, Kumar S, Barnett AH \& Eggo MC 2001 Dexamethasone inhibits tumor necrosis factor-alpha-induced apoptosis and interleukin-1 beta release in human subcutaneous adipocytes and preadipocytes. Journal of Clinical Endocrinology and Metabolism 86 2817-2825. (https://doi. org/10.1210/jcem.86.6.7579)

Zhang SY, Wang JZ, Li JJ, Wei DL, Sui HS, Zhang ZH, Zhou P \& Tan JH 2011 Maternal restraint stress diminishes the developmental potential of oocytes. Biology of Reproduction 84 672-681. (https://doi.org/10.1095/ biolreprod.110.087890)

Zheng LL, Tan XW, Cui XZ, Yuan HJ, Li H, Jiao GZ, Ji CL \& Tan JH 2016 Preimplantation maternal stress impairs embryo development by inducing oviductal apoptosis with activation of the Fas system. Molecular Human Reproduction 22 778-790. (https://doi.org/10.1093/ molehr/gaw052)

Received 21 January 2020

First decision 2 April 2020

Revised manuscript received 6 April 2020

Accepted 24 April 2020 